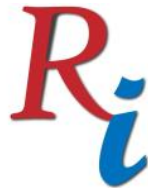

Asia Proceedings of Social Sciences

(APSS)

www.readersinsight.net/APSS

\title{
INNOVATIVE LEADERSHIP OF SCHOOL ADMINISTRATOR AND ITS RELATIONSHIP WITH ICT INTEGRATION IN DISTRICT OF SEREMBAN, NEGERI SEMBILAN.
} Chaw Wei Yeong*

Faculty of Education

National University of Malaysia

Malaysia

\section{Mohd Izham Mohd Hamzah}

Faculty of Education

National University of Malaysia

Malaysia

*Corrosponding author's Email: chaw2ei_yeong@hotmail.com

Peer-review under responsibility of $3^{\text {rd }}$ Asia International Multidisciplanry Conference 2019 editorial board (http://www.utm.my/asia/our-team/) (C) 2019 Published by Readers Insight Publisher, lat 306 Savoy Residencia, Block 3 F11/1,44000 Islamabad. Pakistan, info@ readersinsight.net

This is an open access article under the CC BY-NC-ND license (http://creativecommons.org/licenses/by-nc-nd/4.0/). 


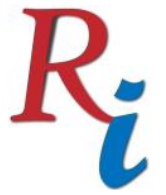

\section{Asia Proceedings of Social Sciences \\ (APSS) \\ www.readersinsight.net/APSS}

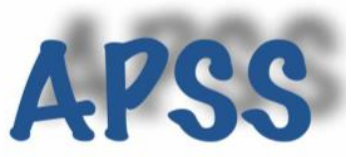

\section{Rese a r ch H i g h I igh t s}

The Malaysia Education Blueprint 2013-2025 has eleven shifts to transform the system. One of it is leverage ICT to scale up quality learning across Malaysia. Integration of ICT in the process of teaching and learning becomes increasingly important from day to day. Integration of ICT in education provides a more dynamic and proactive learning environment (Ghavifek et al., 2014) that students can learn at their own without the limitation of time and place. Therefore, school administrators ( including headmaster, senior assistant administrator, senior assistant of student affairs, senior assistant of co-curricular) who apply their leadership to school, play an important role in order to ensure the integration of ICT (Arokiasamy, Abdullah, \& Ismail, 2015).

The hypothesis of this study proposed that there is a significant relationship between the innovative leadership of the administrator and the integration of ICT. The results indicated there is a positive relationship between innovative leadership of administrators and the ICT integration. With increasing the level of leadership of adminitrators, it can enhance the ICT integration in school.

\section{Research Objectives}

Based on the past studies (Stuart, Mills, \& Remus, 2009; Hadjithoma-Garstka, 2011; Yuen, Law, \& Wong, 2003), there are increasingly attention from the researchers to examine the role of school leaders in ICT integration in education. Hence, this research aims to identify level of innovative leadership of administrators the level of ICT integration in school. Besides, this research explores the relation between practice of innovative leadership of administrator and the ICT integration in school.

\section{Methodology}

The research uses the quantitative approach as the method of survey reseach involving descriptive and inferential analysis. The instrument of this survey is a questionnaire consists of 3 parts. The first part is about the background of respondents including school type, age, position held, highest academic qualifications, and experience as administrator. Second part referred to self evaluation of innovative leadership of school administrators and the last part is about the level of ICT integration in school. In this study, the respondents were required to mark $(\sqrt{ })$ in the bracket provided for the first part while for the second and third part, the respondents used the 5-point Likert Scale to answer the questionnaire. The 5-point Likert scale ranged from $5=$ Strongly agree, $4=$ Agree, $3=$ slightly disagree, $2=$ disagree, $1=$ strongly disagree. The interpretation of 5- point Likert scale are as the table below.

\begin{tabular}{cc}
\hline Average of Score & Interpretation \\
\hline $1.00--1.80$ & Very low \\
$1.81--2.60$ & Low \\
$2.61-3.40$ & Moderate \\
$3.41--4.20$ & High \\
$4.21--5.00$ & Very high \\
\hline
\end{tabular}

The research was conducted in primary school in district of Seremban, Negeri Sembilan. The population of this research is all the school administrators (headmaster, senior assistant administrator, senior assistant of student affairs, senior assistant of co-curricular) who are currently serving under Ministry of Education Malaysia. The samples are randomly selected. 


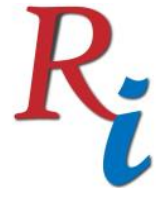

\section{Asia Proceedings of Social Sciences (APSS) \\ www.readersinsight.net/APSS}

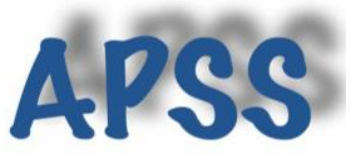

\section{Results}

The total number of respondents who took part in this research was 234 people. That is a response rate of approximately 78.52\%. Based on the Statistical Package for Social Science (SPSS) analysis, overall, the findings show that the level of innovative leadership of the administrators in district of Seremban, Negeri Sembilan is at a very high level (mean $=4.354$, standard deviation $=0.339$ ). Furthermore, the result of the ICT integration is at high level (mean $=4.105$, standard deviation $=0.414)$. On the other hand, the Pearson's correlation are used to explores the relation between the practice of innovative leadership of administrator and the ICT integration in school. The result shows that there was a positive correlation between the practice of innovative leadership of administrator and the ICT integration in school, $\mathrm{r}=$ $0.441, \mathrm{p}<0.001$. The hypothesis of this study proposed that there is a significant relationship between the innovative leadership of the administrator and the integration of ICT, therefore, the hypothesis is accepted.

\section{Findings}

The data analysis showed that both the level of innovative leadership of school administrators and ICT integration are at high level and there is a significant relationship between this two variable. This shows the importance of role playing by school administrator to enhance the ICT integration in school by leading all the teachers towards the same direction of goal that stated in Malaysia Education Blueprint 2013-2025. In addition, both the school administators and teachers are required to equip themselves with various skills in ICT so that they could apply in the process of teaching and learning which will benefit the students.

\section{References}

Arokiasamy, A.R.A., Abdullah, A.G.K., \& Ismail, A. (2015). Correlation between cultural perception, leadership style and ICT usage by school principals in Malaysia. Procedia-Social and Behavioral Science ,176(2015), 319-332. Retrieved from doi: 10.1016/j.sbspro.2015.01.478

Ghavifekr, S., Abd Razak, A.Z., Muhammad Faizal A., Ng, Y.R., Yao, M. \& Zhang, T. (2014). ICT integration in education: incorporation for teaching \& learning improvement. The Malaysian Online Journal of Educational (2)2, 24-45.

Hadjithoma-Garstka, C. (2011). The role of the principals' leadership style in the implementation of ICT policy. British Journal of Educational Technology 42(2), 311-326. http://doi.org/10.1111/j.14678535.2009.01014.x

Stuart, L. H., Mills, A. M. \& Remus, U. (2009). School leaders, ICT competence and championing innovations. Computers \& Education 53, 733-741.

Yuen, H. K., Nancy Law, K. C. \& Wong, K. C. 2003. ICT implementation and school leadership: Case studies of ICT integration in teaching and learning. Journal of Educational Adminstration 41(2), 158-170. http://doi.org/10.1108/09578230310464666 